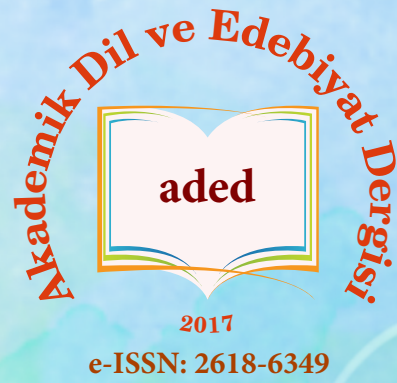

\author{
Akademik Dil ve Edebiyat Dergisi \\ Academic Journal of Language an literature \\ Cilt: 3, Say1: 1, (Nisan 2019)
}

Divan Şiirinde Para Birimlerinin Gerçek Anlamı Dışında Kullanımı*

Use Outside The Real Meaning of The Currencies in The Divan Poetry

\title{
Yahya YÜKSEL*
}

${ }^{\star}$ Dr., Milli Eğitim Bakanlığ 1

e-mail: sara_yahya@hotmail.com

Araştırma Makalesi / Research Article Article DOI: https://doi.org/10.34083/akaded.543128

Sorumlu Yazar / Corresponding Author

Yahya Yüksel, Giresun Piraziz Anadolu Lisesi, Giresun / Turkey

\section{ORCİD : 0000-0002-4714-0145}

Geliş Tarihi / Received : 21.03 .2019

Kabul Tarihi / Accepted : 04.04.2019

\section{Atıf / Citation}

YÜKSEL, Yahya (2019). Divan Şiirinde Para Birimlerinin Gerçek Anlamı Dışında Kullanımı. Akademik Dil ve Edebiyat Dergisi, 3 (1), 75-95. DOI: 10.34083 /akaded.543128

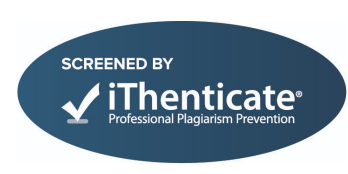

\section{Öz}

İnsanoğlunun tüketebileceğinden veya ihtiyacından fazlasını üretmeye başlaması ticaretin ortaya çıkmasındaki önemli etkenlerden biri olmuştur. Üretim fazlasını kendinde olmayanla değiştirme isteği başlangıçta trampa denilen takas yöntemini doğurmuş, bu yöntem zamanla ürün mübadelesinde değerli kumaş, deri ve madenlerin kullanılmasına önayak olmuştur. Ticari faaliyetlerinin ülke sınırları dışına taşıp uluslararası boyuta taşınması ile alışverişin hızlı ve kolay yapılması isteği veya arayışının sonucunda para bulunmuştur. Parayla birlikte ticari faaliyetler daha kolay ve geniş̧ coğrafyalarda yapılmaya başlanmış ve ekonomik hayat, maddi refah, zenginlik gibi unsurlar bir devlet için en az siyasi veya askeri güç kadar önem arz etmiştir. Yaşadığı coğrafyada söz sahibi olmak ve dünya siyasetine yön vermek isteyen her devlet gibi Osmanlı Devleti de ticarete önem vermiş, bunun için sıkı para politikaları izlemiştir. Yüzyıllar boyunca hem örnek alıp başka devletlere ait para birimlerini kullanmış hem de kendi para birimlerini üretmiştir. Maddi kültür unsurlarından olan para birimleri, içinde bulunduğu toplumun parçası olan ve bu topluma ait her türlü malzemeyi şiirlerine yansıtan divan şairleri tarafından şiirde bir malzeme olarak kullanılmıştır. Kuşkusuz bu kullanım para birimlerinin gerçek manaları veya alışverişteki maddi kullanımlarıyla sınırlı kalmamıştır. Sanatçı hassasiyetinin devreye girmesiyle para birimleri çeşitli teşbihler ve mecazlı kullanımlarla, atasözü ve deyimler eşliğinde, gelenek ve kültüre ait kavramlarla karşımıza çıkmıştır. Bu çalışmada incelediğimiz divan ve mesnevilerde, Osmanlı devletinin kuruluşundan 19. yüzyıla kadar tedavülde olan madeni para birimlerinin gerçek anlamı dışında nasıl kullanıldığı, âdet-gelenek içerisinde nasıl konu olduğu ve hangi benzetmelere konu edildiği üzerinde duracağız.

Anahtar Kelimeler: Divan şiiri, para birimleri, mecaz, benzetme.

\begin{abstract}
The fact that human beings can consume more than their needs or consumes has been one of the important factors in the emergence of trade. The desire to replace the surplus with the non-self has given rise to the so-called swap method, which has led to the use of valuable fabrics, leather and mines in the product exchange over time. Money was found as a result of the desire or quest of making the trade quick and easy by moving the commercial activities out of the borders of the country to the international dimension. With the money, commercial activities were started to be made more easily and in large geographies and economic life, material wealth and wealth were as important as a political or military power for a state. Like every state that wants to have a voice in the geography of the country and to give direction to the world politics, the Ottoman Empire gave importance to trade, followed by tight monetary policies. For centuries, he took examples and used the currencies of other states and produced their own currencies. Currencies, which are elements of material culture, have been used as a material in poetry by dîvân poems which are part of the society and which reflect all kinds of materials belonging to this society to their poems. Undoubtedly, this use is not limited to the real meaning of the currencies or the material use in the exchange. With the introduction of the sensitivity of the artist, the currencies have come up with concepts of tradition and culture, accompanied by various conventions and metaphorical uses, proverbs and idioms. In this study, we will examine how the Ottoman Empire was used in the period of the 19th century until the nineteenth century.
\end{abstract}

Keywords: Classical Turkish poetry, currencies, metaphor, analogy.

${ }^{\star}$ Bu çalışma 15-17 Mart 2019 tarihleri arasında UBAK (Uluslararası Bilimler Akademisi) tarafından Giresun'da düzenlenen Karadeniz I. Uluslararası Multidisipliner Çalışmalar Kongresi'nde sunulan bildirinin gözden geçirilmiş ve genişletilmiş hâlidir. 


\section{Giriş}

Paraya karşı olan istek, ortaya çıktığı ilk günden beri coğrafyası, dili ve dini fark etmeksizin her toplumda kendini göstermiştir. Kuşkusuz bu durumun oluşmasında insanların hayatlarını idame ettirme isteği yani geçim düşüncesi, servet sahibi olma arzusu, biriktirerek yatırım yapma isteği gibi durumlar etkili olmuştur. Devletler düzeyinde düşününce bir devletin gücünün belirlendiği en önemli ölçütlerden biri hazinesinin doluluğu, ticarete verdiği önem gibi ekonomik unsurlar olmuştur. Yeri gelmiş ticaret yollarının hâkimiyeti uğruna savaşlar yapılmış yeri gelmiş ülkeler arasında siyasi kriz dönemlerinde en azından ekonomik faaliyetler devam etmiştir. Tüm bunlar servetin, zenginliğin veya paranın öneminin tarihin her döneminde üst düzeyde olduğunun bir göstergesidir.

$\mathrm{Bu}$ dönemlerden biri de yaklaşık 600 yıllık Osmanlı devridir. Hâkimiyet göstergesi olarak ilk Osmanlı parası olan akçenin 1326 yılında Orhan Bey zamanında basılmasından son dönemlerdeki kâğıt para kaimenin ortaya çıkmasına kadar devam eden bu süreçte altın, gümüş ve bakırdan üretilen çok çeşitli para birimleri kullanılmış ve bunlar değişik isimlerle anılmıştır. Tıpkı günümüzdeki gibi sadece Osmanlı'nın kendine ait para birimleri değil, ticari ilişkiler ve komşuluk ilişkileri vesilesiyle bağlantı halinde olunan devletlere ait paralar da ülkede tedavülde olmuş ve bu durum Osmanlı devletinin esnek ekonomi politikasını göstermesi bakımından önem arz etmiştir (Pamuk, 2013: 113. Pamuk, 2014: 25-41. Akyıldız, 2007: 164. Ölçer, 1984: 205. Pakalın, 1983: 32. Sahillioğlu, 1989: 224. Sami, 2015: 43).

Maddi kültürün vazgeçilmezlerinden olan para, toplumun hemen her ferdini az ya da çok ilgilendirdiği gibi yaşadığı toplumun parçası olan divan şairleri tarafından da şiirlerinde sıklıkla kullanılmıştır. Kuşkusuz şiirlerde sadece gerçek anlamıyla alışverişte mübadele aracı olması bakımından ilgi çekmemiş; çeşitli benzetmeleri, mecazlı söyleyişleri, âdet ve gelenekleri en güzel ve sanatlı şekilde ifade etmek için divan şairlerine zengin birer malzeme olmuştur. İncelediğimiz farklı yüzyıllara ait eserlerde akçe, altın-gümüş, bakır, çil, dinar ve dirhem, eşrefi, filori, füls-i ahmer, kızıl altın, mangır, nakit, nuhas, nukre, para, peşiz, pul, sikke, sultânî, sikke, sülüs, şâhî, yaldız, yalvar, zincirli fındık altını, zer-i hûb isimli para birimlerini, paraların basıldığı madenleri tespit ettik ve bunları gerçek anlamı dışında kullanımlarını incelemeye çalıştık.

Para birimlerinin gerçek anlamı dışında kullanımına bakacak olursak ele alınacak ilk para birimi, Osmanlı'nın da temel para birimi olan akçedir.

Akçe: Osmanlı’nın kuruluş yıllarından itibaren tedavülde olan gümüş paradır. Her ne kadar ilk Osmanlı akçesinin Osman Bey zamanında basıldığı söylense de ,o dönemde Anadolu'da İlhanlı etkisi devam ettiğinden, bağımsızlık sembolü olarak ilk akçenin Orhan Bey zamanında son İlhanlı valisinin Mısır'a sığınmasından sonra 1326'da basılan akçe olduğu kaynaklarca genel kabul görmüştür. İlk başlarda gümüş sikke anlamında kullanılan akçe özellikle 15. yy.'dan itibaren de genel olarak "para" anlamında kullanılmıştır. Türkçe beyaz, parlak, temiz anlamına gelen "ak" kelimesinden türediği ve gümüş olduğu için de beyaz sikke dendiği kabul edilmektedir (Akdağ, 2007: 356. Tabakoğlu, 2014: 391-397. Pamuk, 2013: 113. Pamuk, 2014: 25-41. Akyıldız, 2007: 164. Ölçer, 1984: 205. Pakalın, 1983: 32. Sahillioğlu, 1989: 224. Sami, 2015: 43).

Divan şairleri tarafından akçe denince gerçek anlamı dışında kelimenin en sık kullanımlarından biri gözyaşı ile olan benzerliği olmuştur. Gözden akan yaş, beyaz ve şeffaf olduğu için renk itibariyle akçeye teşbih edilmiştir. Nakit yani para, dünya varlı̆̆ı içinde en değerli şeylerden biridir. Âşık için sevgili uğruna feda edilen her şey nasıl değerliyse bu uğurda akıttığı gözyaşı da para gibi değerli bir nesneyle ifade edilir. Zâtî, beytinde Türk insanının en çok bildiği ve yüzlerce yıldır kullandığ 1 “Ak akçe kara gün içindir.” atasözünü kullanarak sevgiliden ayrılığı kara gün olarak 
düşünür. Kişiyi maddi olarak yaptığı yatırımlar nasıl zor durumdan kurtarırsa âşığı da sevgilinin ayrılığından dolayı düştüğü sıkıntıdan gözyaşı nakdi, akçası kurtaracaktır. Beyitte ayrıca toplum tarafından genel bir kabul olan, ağlamanın insanı ruhen rahatlandığı düşüncesini de çıkarabiliriz:

Döküb saçmaga hecründe dem-i nakd eşküm ey meh-rû

Ag akçe kara gün içün dimişlerdür meseldür bu

(Zâtî, G. 1228-1)

Bu gözyaşı bazen o denli çoktur ki kanlı gözyaşına yani kızıl akçeye döner:

Kızardı akçesi 'aynun ele girerse cevherdür

O şemsün kalbümüz ayagı altından türâb ister (Zâtî, G. 465-2)

Necâtî Bey, Allah karşısında işlediği günahlardan ötürü düştüğü kötü durumu "yüzü kara olmak" deyimiyle ifade etmiş; kara olan yüzünü ağartması yani onu içinde bulunduğu sıkıntılı ruh halinden kurtarması için akıttığı gözyaşlarını da akçeye benzetmiştir:

Çok günâhıma çok gözüm yaşı var

Yüzü karaysa akçesi aktır （Necâtî Bey, G. 147-6)

Bu durum gönül ehli olanlara büyük mutluluk verir:

Akdukça nakd-i eşk çogaldukça akçası

Artar safâsı ehl-i dilüñ kâm-rân olur (Süheylî, G. 90-4)

İnsanlar daima değerli olanın peşinde olmuştur. $\mathrm{Bu}$ anlamda para dini, dili ne olursa olsun herkesin sahip olmak istediği bir nesnedir. Âşık için değerli olan sevgili de tüm sevenlerin peşinden koşup ona kavuşma isteği düşüncesinden hareketle akça olarak düşünülmüştür:

$\mathrm{Ne}$ 'aceb akça diyen hûbı seversem ey dil

Yalınuz ben degülem akçaya dünyâ mâ’il

(Mânî, G. 56-1)

Dünya malı olarak değerlendirilen akçe insanı bir çok kötülüğe ittiği için el kiri gibi değersiz bir nesneye benzetilir:

Dünyâda akçe el kiri idi elüm yudum

Alsam safâyile yiridür şimdi câm-1 Cem

(Vücûdî, M. 3419)

Göz, akıttığı akçe gibi gözyaşlarını hesaplayan bir tüccar olur:

Çeşmüm ki Rahmiyâ akıdur sîm-i eşkini

Bir hâcedür ki akçelerini hisâblar (Bursalı Rahmî, G. 58-5)

Akçe ile ilgili deyimlere de divan şairleri tarafından sıklıkla yer verilmiștir. Paranın kazanmakla değil tutumla artacağını ifade eden "dişten artmaz işten artar", değeri olmak anlamına gelen ve günümüzde de para etmek şeklinde kullanılan "akçe etmek", başkasına ait parayı haksız şekilde harcamak anlamında "yetim akçası yemek" bunlardan birkaçıdır.

Dişden artar akça işden artmaz dirler şehâ

Gözlerüm yaşın ne var artursa dendânuñ senüñ

(Emrî, G. 263-3)

Masharalık akçe ider zann idüp

Kendüne gel zerre hitâb itme sus （Tirsî, G. 98-4)

Yetim akcasını kim yerse her bâr

Degüldür âdemî bil kelb-i bâzâr

(Firâkî, M. 2635) 
Klasik şiirin kaynaklarından olan âdet ve gelenekler şiirlerde karşımıza sıklıkla çıkmaktadır. Bunlar arasında para ile ilgili olanlar da mevcuttur. Bunlardan biri saçı veya nisar denilen gelinlerin başlarından para atılmasıdır. Beyitte lâle al duvaklı bir gelin ve taze fidanlar da onun üzerine yağmur misali akçe saçan kimselerdir. Yağmur renk itibariyle de akçeye benzetilebilir:

Nitekim lâle ola al duvağı ile arûs

Her nihâl akçe saça üstüne bârân-şekil (Hayâlî̀, K. 8-32)

Vücûdî, insanın samimice ettiği duaları Allah'ın kabul etmesini başa akçe saçma geleneği ile ifade etmiştir. Kişinin üzerine para saçılması o kişi için dağıtılan paraların maddi değerinden çok daha fazlasını ifade eder. Allah'tan istediği şeylerin kabulü için ellerini semaya kaldıran bir müminin duasına bulduğu karşılık da bu denli değerlidir:

Kim recâ-yı du'âya destin açar

Taslarla başına akçe saçar （Vücûdî, M. 1813)

Necâtî Bey, beyitte gözyaşı ile akçe arasında ilişki kurarken sevgilinin olduğu yeri Kâbe olarak düşünür. Oraya ulaşmak kolay bir şey değildir. Eski dönemlerde hac vazifesi ,ulaşım kervanlarla yapıldığından, hem çok uzun sürer hem de oldukça masraflı olurdu. Tıpkı bunun gibi, âşığın sevgilinin kapısını tavaf etmesi için akçeye benzeyen gözyaşının çok olması gerekir:

Gözüm yaşından umardım kapın tavâf etmek

Veli çok akçeli olur ki hac nasîb olmaz

(Necâtî Bey, G. 221-2)

Devlet büyüklerinden, onların hizmetinde bulunan kişilerin maddi beklenti içinde olması ve bu beklentiye devletlülerin ihsanla, akçayla karşllık vermesi bir gelenek olmuştur. Günümüzdeki bahşiş verme âdetini hatırlatan bu gelenek, beyitte âşıkların gönüllerinin gümüş tenli güzellerden kavuşma isteğinde bulunmasılyla ilişkilendirilmiştir:

Sîm-tenler vaslın eyler hâtır-1 şeydâ ricâ

Bir gedâ devletlülerden akça eyler iltimâs ～(Mostarlı Hasan Ziyâi, G. 189-4)

Nâbî ise dilencilere para verme geleneğinden bahseder. Ayın hilâl şeklinde olması âşığın sevgili için çektiği sıkıntılardan dolayı zayıflaması veya ihtiyar olup kamburlaşması olarak da düşünülmüştür (Pala, 1999: 45-46). Beyte bu açıdan bakılacak olursa alçak olarak değerlendirilen felek ,tıpkı çanağına hiç akçe bırakılmayan dilenci misali, âşığın sevgiliye kavuşma isteğine engel olmuştur:

Bin kez tutarsa kâse-i deryûzesin hilâl

Çerh-i denî bir akçe bırakmaz çanagına

(Nâbî, G.742-7)

\section{Altın-Gümüş (Zer-Sîm)}

Osmanlı döneminde basılan paraların hammaddelerinden olan gümüş ve altın, şiirlerde genellikle Farsça sîm ve zer şeklinde de kullanılmaktadır. Aynı başlıkta birlikte ele almayı bu açıdan uygun gördük.

Altın, MÖ 3000 yıllarında ortaya çıktı̆̆ı ilk günden bu yana insanların en çok değer verdiği ve değerini hiç yitirmeyen bir madendir. Yumuşak ve sarı renkte olan altın işleme kolaylığı ve güzelliğinden dolayı diğer madenlerden üstün tutulmuş, birçok farklı alanda sanat eserine malzeme olmuştur. Özellikle kuyumculuk dendiğinde akla gelen ilk madendir. İlk Sümerler tarafından kullanıldığı tahmin edilen altından para ise MÖ 7. yüzyılda basılmıştır. Osmanlı döneminde ise ilk altın para Fatih Sultan Mehmet zamanında 1478-1479 yıllarında "sultani" adıyla basılmıştır. Gümüş ise MÖ. 2500 yıllarında bulunmuş, ilk önce Çinliler, Farslar ve Türkler 
tarafından kullanılmıştır. Parlak, güzel ve paslanmaz özelliğe sahip gümüş her türlü süs ve ziynet eşyası yapımında kullanılmış, bu özelliği sayesinde elde ettiği değerle altından sonra para üretiminde ön planda olan ikinci maden olmuştur. İlk Osmanlı gümüş parası akçe 1326 yılında Orhan Bey zamanında basılmıştır (Kuşoğlu, 2006: 22-93. Kolerkılıç, 1958: 26. Pakalın, 1983: 32).

Şiirlerde genel manada para anlamında kullanıldığı ve para üretiminin temel madenleri olduğu için ayrı bir başlık altında işlediğimiz altın ve gümüş özellikle insan kişiliğinin ifade edildiği durumlarda benzetme unsuru olarak karşımıza çıkmaktadır.

İnsan ve onun manevi açıdan değerli oluşu, en itibarlı maden olan altınla ifade edilmiştir. Saf altın kırılmış olsa bile değerinden bir şey kaybetmeyeceği gibi kemal ehli bir insan kıymetinin bilinmediği durumlarda bile itibarını asla yitirmez:

Kemâl erbâbı kesr-i kadr ile bî-i’tibâr olmaz

Zer-i hâlis şikeste olsa da nâkıs-'ayâr olmaz （Sümbülzâde Vehbî, G. 106-1)

Gelibolulu Mustafa Âlî̀ye ait beyitte ise altın gibi değeri olan kimsenin değerini bilememenin pişmanlığ ifade edilmiştir:

Kiymetin bilmedüm o mâhzûnuñ

Hâke sürdüm yüzüni altunuñ （Gelibolulu Mustafa Âlî, M.707)

İnsan kalbi, içinde barındırdığı iyi veya kötü fikirler açısından altın veya gümüşe teşbih edilir. Günahını itiraf eden kişinin kalbi saf altın olarak düşünülür:

Kıldı günehine i'tirâfı

Mânend-i zer oldı kalbi sâfî̀ (Nev’izade Atayi, M. 342)

Divan şiirinde altın ve gümüş söz konusu olduğunda en sık yapılan benzetmelerden biri âşığın sararmış yüzünün altına; sevgilinin teninin, âşığın gözyaşının veya gözün gümüşe benzetilmesidir.

Vücûdî, altına benzeyen sararmış yüzün ayarı düşük altın gibi sevgili katında bir değeri olmadığını söyler. İkinci beyitte Zâtî ise gümüş tenli sevgilinin bir sözüyle sararmış ve altına benzemiş yüzünü onun ayakları altına seve seve sermek ister:

Çehre kim zer gibi 'ayârı yok

Yâr yanında i'tibârı yok

(Vücûdî, M. 2242)

Ey sîm-ten sözün yüzi üstine Zâtînnün

Tek ferş içün sen ayagun altına zer dile

(Zâtî, G. 1360-5)

Âşık, gümüş gibi gözyaşı ve altın gibi sararmış yüzünden asla rahatsız olmaz. Aksine bunlar âşık için aşk yolunda birer süstür. Bunlar aynı zamanda aşk mülküne girmek için olmazsa olmaz özelliklerdir:

Eşk-i sim ü rûy-i zerden incine sanma beni

'Âşk yolunda beğim bunlar tecemmüldür bana

(Necâtî, G. 15-4)

Her kimün 'aynı gümüş̧den sûreti zerden degül

Mülk-i ‘şka girmeyüpdür bizüm illerden degül

(Zâtî, G. 823-1)

Divan şairi, sevgilinin değerinin bilinmesi noktasında kendisini kuyumcuya benzetir. Hayâlî Bey, gümüş tenli sevgiliye seslenir ve kendisini de aşk sarrafı olarak niteler. Altının kıymetini nasıl sarraf bilirse yüz ve bedeni gümüş gibi parlak sevgilinin değerini de ancak kendisi bilir:

Aşk sarrâfına göster yüzün ey sim-beden 
Ne bilir câhil olan kıymetini altûnun (Hayâlî Bey, G. 290-3)

Beyitte Feyzullah Nâfiz para birimi olan "nakd, pul, pare, zer-i mağşuş" kelimelerini tenasüplü kullanır. Mağşuş, içerisindeki altın oranı azaltılmış ve değeri düşürülmüş paralar için kullanılan bir tabiridir. Âşığın niyāz etmesi yani yalvarması sevgili katında bakır para pul kadar bile değer görmemiş, zer-i mağşuş gibi değersiz kabul edilmiştir:

Naḳd-i niyāz geçmedi bir pūla gördüler

Bir pāre yalvarıp zer-i magşūşa çekdiler

(Lâzikîzâde Feyzullah Nâfiz, G. 205-2)

Necâti Bey’e ait beyitte sevilinin güzel bakışlarının toprağı altına çevirecek gücünden bahsedilir. Kendisi de onun ayağının toprağı olan samimi bir kölesidir:

Toprağı altın eder cânâ iyi bakışların

Bende-i muhlis Necâtî de ayak toprağıdır ～(Necâti Bey, G. 186-7)

Tasavvufi açıdan kalp temizliği altın ve gümüşle ilişkilendirilir. Kalbinde güzellikler barındıran, Allah yolundan gidip fakirlik ve alçakgönüllülüğü kabul eden, tarikata girmiş kimseye derviş denir. Yunus Emre dervişliğin Allah tarafından bağışlandığını düşünür. "Kalb” sözcüğü burada sahte, güvenilmez anlamında kullanılmış ve insanın kişilik olarak değerini ifade etmiştir. Değersiz, kalp olan paranın nasıl ki içinde gümüş oranı düşükse ve insanlar arasında değeri bulunmazsa kötü düşünceye sahip insanların da Allah katında kıymeti az olur. Dervişlik nasip olan kişi de saf gümüşten yapılmış sahte olmayan para gibi üstün bir seviyeye ulaşır:

Her kime kim dervîşlik bagışlana

Kalbı gide pâk ola gümüşlene (Yunus Emre, G. 324-1)

Emrî ise eskiden altın paraların günümüzün cüzdanı sayılan kesede taşınması olayına telmihte bulunarak kefeni bir keseye, bedeni ise onun içine konulmuş değeri yüksek altın paraya benzetir:

Pür eyledüm zer-i nâb ile kîse-i kefenüm

Çü tura haşrda bâzâr olam harîdâruñ （Emrî, G. 283-2)

Söz, eğer doğru ve düzgün kullanılırsa altın gibi değerli olur. Kişinin temiz yaradılışı ise sözün değerini belirleyen mihenk taşı gibidir. Mihenk taşı nasıl altının değerini ortaya dökmede bir ölçütse düzgün yaratılış da hem kişinin değerini hem de sözün güzelliğini ortaya çıarır. Zaten mayası bozuk insanların bedenleri toprak olup dedikleri unutulmaya mahkumdur:

Zer suhan tab'-1 pâki aña mehek

Kem-'ayâruñ vücûdın eyler hâk

(Vücûdî, M. 217)

Sözle ilgili "Söz gümüşse sükût altındır." atasözü divan şairleri tarafından nasihat verirken kullanılmıştır:

Söz gümüşdür velî sükût altun

Saña altun olur gümüşden ehem （Vecdî, K. 13-26)

Bazen güneş başında altın tepsisi taşıyan bir kişi gibi düşünülür ve altına benzeyen güneş ş̧ıklarını taşır şekilde tasvir edilir. Bazen de nergis, çemen çarşısında dükkânı olup müşterisinin önüne altın seren bir kuyumcu gibi düşünür:

Götürüp tepsi ile başda zer

Her gün ider güneş o yola sefer

(Vücûdî, M. 393)

Çâr-sû-yı çemen içre yine dükkâna geçer

Sayrafîler gibi dizdi öñüne zer nergis (Ravzî, G. 351-2) 
Necâti Bey ise sabah seher vakti tan yerinin ağarmasını ve güneşin doğuşunu altın ve gümüş benzetmesiyle canlı bir tablo gibi sunmaktadır:

Her subh sim ü zer döker eflâk eşigine

Oldur ki mihr zer gibidir sîm-sâ seher (Necâti Bey, K. 9-37)

İşin altın veya gümüş olması ya da altın adın bakır olması, divan şiirinde insanın itibarının iyi veya kötü durumunu ifade etmek için kullanılan tabirlerdir. (Şentürk, 2016: 282) Necâtî Bey harabat ehli olanlar için kişinin değerini, itibarını arttıran şeyin kadeh ve şarap olduğundan bahseder. Dolayısıyla harabat da en büyük zenginlik mekânıdır:

İşini altın eden meydir gümüş peymânedir

Ol harâbât ey birâder şimdi devlet-hânedir （Necâtî Bey, G. 60-1)

Burada şarap, altının bakır gibi değersiz madenlerden ayrılmasında kullanılan mihenk taşına benzetilir. Harabat erenlerinin itibarını o belirler. Şükürler olsun ki Necâtî bu sınavı vermiş, bu devlet-hânede itibarını kaybetmemiştir:

Derler mihak şarâba harâbât erenleri

Şâd ol gönül ki altın adın bakır olmadı

(Necâtî Bey, G. 600-3)

\section{Bakır}

Esmer ve kırmızı renkte bir maden olan bakır özellikle altın ve gümüşün ayarının düşürülmesinde kullanılır. Yine altın ve gümüşün kızıla çalan bir renkte olması içindeki bakır oranıyla alakalıdır (Kuşoğlu, 2006: 35). Mangır veya pul gibi değeri düşük ve çarşı-pazar alışverişinde bozuk para niyetiyle darp edilen paralar bakırdan yapılmıştır.

Zâtî beyitte, sevgilinin güzelliğini başkalarının seyrettiğini söyler; ancak onun kendisine görünmediğinden de şikâyetçidir. Gözlerinden döktüğü akçe gibi değerli kanlı gözyaşları bakır gibi değersiz midir de sevgili böyle davranmaktadır:

İl cemâlün seyr ider cânâ görünmezsin bana

Yohsa pür-hûn gözlerümün akçesi bakır mıdur

(Zâtî, G. 174-3)

Tırsî yaradılışındaki güzelliği, değerinin yüceliğini cevher olarak düşünmüştür. Ancak içinde bulunduğu ve değerinin bilinmediği bu yer ise bir süprüntülük veya çöplüktür. Bu insanlar arasında değeri bakır gibi düşük bulunmuş ve bilinmemiştir. $\mathrm{O}$ da bu duruma kahretmiş ve suskun kalmıştır:

Süpründilikde kalmış Tırsî gibi cevâhir

Çıkdı bakır ayârı kahrından oldı hâmûş

(Tirsî, G. 91-6)

Divan şiirinde ağız, hikmetli ve inci gibi değerli sözlerin saçıldığı bir hazine veya maden olarak düşünülür. Tırsî bu beytinde değerli, riyadan ve günahtan arınmış sözleri madenden çıkartılan saf altına benzetmiştir. Ancak bu değerli madene sahip olamayıp kalbi ve zikri temiz olmayan insanların dedi kodu dolu sözleri ise bu madenden çıkan bakırla karışık altın gibi ayarı düşük, değersiz şeylerdir:

Ma'deninde pîç gibi bakır çıar külçe gelür

Böyle mahlût olduğından kîl ü kâl eksük değül

(Tirsî, G. 126-4)

Şiirde nasıl ki tenin ve bedenin gümüşe, yüzün altına benzetilmesi değer ifadesiyse vücudun bakır gibi olması da kişinin kemal ehli olmadığının bir göstergesidir. Fuzûlî insanın bu durumdan 
kurtulmasının yolunu ise vefa sarrafının vücut bakırını edep potasına atıp orada ateşle terbiye ettikten sonra her türlü kinden ve düşmanlıktan arıtıp saf hale getirmesinde bulur:

Sarrâf-1 vefâ pûte-i te' dîbe salıp

Her giştan ede miss-i vücüdünu halas （Fuzûlî, Rubâi 38)

Altın ve gümüş başlığı altında açıkladığımız, kişinin değer ve itibarını ifade eden "altın adın bakır olması" deyimine burada da bir örnek vermek uygun olacaktır. Beyitte Zâtî sevgiliye seslenir ve ona altın değerinde bir nasihatte bulunur: Ey sevgili! Zâtînnin ögüdünü tut ve paraya değer verme. Yoksa bu dünyada altın adın bakır olur, değerin bilinmez.

Meyl itme sîm ile zere tut pend-i Zâtîyi

Cânâ cihânda olmasun altun adun bakır

(Zâtî, G. 410-5)

Çil

Kelime ala dediğimiz karışık renk, beyaz, boz ve kır renk anlamlarına gelir. Çil aynı zamanda kırk paralık gümüş sikke için kullanılan bir tabirdir. Genelde, gümüş olduğu için akçe ile birlikte "çil akçe" şeklinde kullanılmakla birlikte ayarı tamam, yeni basılmış madeni paralar için tercih edilen genel bir ifade olmuştur (Dilçin, 2009: 68. Pakalın, 1983: 370. Kuşoğlu, 2006: 58).

Süreyya, toplam yedi yıldızdan oluşan bir yıldız kümesidir. Ülker veya Pervin de denilir. Tüm bu yıldızlar feleğin içerisindedir ve felek şiirde genelde şikâyet unsuru olarak ele alınır. Süreyya Ay’ın etki alanında olduğu için sevgilinin yüzü ay olarak düşünüldüğünde Süreyya'daki yıldızlar ise sevgilinin benine teşbih edilir. Bu benler beyitte feleğin harcamaya kıyamadığı birer gümüş çil akçe gibidir:

Felek kıyâmete dek harca kıymaz ey Nâbî

Beş on çil akçesi var sürre-i Süreyyâda （Nâbî, G.702-8)

Dünyanın boşluğunu ve insanların sahtekârlığını dile getirdiği beytinde Nâbî para ile ilgili "kîse-tehî, kallâb, nukre, çil akçe" kelimelerini ve coğrafyayla ilgili "âlem, husûf, sipihr, mâh" kelimelerini kullanmıştır. Ay tutulması olayından bahsedilirken ay ile parlaklık ve renk bakımından çil akçe arasında ilgi kurulmuştur:

Nâbî o kadar kîse-tehî dünyâ kim

Kallâbliga başladı câlem yek-ser

Mikrâz-1 husûf ile sipihr-i kallâb

Çil akçe diyü nukre-i mâhı kırkar

(Nâbî, Rubâcî 68)

Şiirde genel de sevgiliden haber getirmesi yönüyle ele alına sabâ rüzgârı Lebîb’e ait beyitte badem çiçeklerini gül bahçesine çil para olarak saçması yönüyle ele alınmıştır. Burada badem çiçekleri de çil para olarak düşünülür:

Sabâ çil para saçdı gülşene ezhâr-ı bâdâmı

Hevâ gûyâ mevâcib-dâde-i Bektâşiyân oldu （Lebîb, K. 6-8)

Yine bir tabiat olayından bahseden Mânî, karakış mevsiminde karın yağıp her tarafı kaplamasını çil akçe saçma geleneğine benzeterek ifade etmiştir:

Saçıldı âleme çil akçe erbaî̀n içre

Ki toldı ceyb-i cibâl ile dâmen-i sahrâ （Mânî, K. 3-5)

\section{Dinar- Dirhem}


Altın ve gümüşte olduğu gibi dinar ve dirhem de şiirlerde genellikle birlikte kullanılır. Kökeni Roma'ya dayanan altın para dinar ve Yunanlılara dayanan gümüş para dirhem İslam devletleri tarafından kullanılmıştır. Osmanlı döneminde resmi kayıtlarda zikredilse de bu isimle özellikle para basılmamıştır.

Süheylî̀ye ait beyitte aşığın vücudundaki kanlı yaralar renk ve şekil itibariyle dinara benzetilmiştir:

Dâg-1 hûnînüm kızıl dînâr ü eşküm akçedür

Baña yüz sürmek cemâlüñ Ka'besine oldı farz （Süheylî. G. 146-3)

Vusûlîye ait bu beyitte olduğu gibi bazen de âşı̆̆ın gümüşe benzeyen gözyaşı dirhem, altın gibi sararmış yüzü ise dinar olarak düşünülür:

Sîm-i eşk ü çihre-i zerd-ile yüz bulsam n'ola

Kadrin arturan kişinün dirhem ü dînârdur (Vusûlî, G. 40-3)

Gözyaşı bazen o kadar çoktur ki o akçe terazisindeki dirhem gibidir. Eskiden madeni paraların sayımı için akçe tahtası kullanılır, eğer ticaretin hacmi büyük ve alış-verişte çok miktarda para söz konusu olursa da akçe terazisi devreye girer, paralar burada tartılırmış. Bu gerçekten hareketle aşığın çektiği sıkıntı daha iyi anlaşılabilir:

Göñül ey sîm-ten sarrâf-1 şehr-i mihnet ü gamdur

Gözüm akça terâzûsı sirişküm aña dirhemdür

(Emrî, G. 161-1)

Mihnet ve gamın çekildiği aşk ülkesine gözyaşı dirhemi olmadan Kârun bile gelse bunca malıyla ona her şeyini kaybetmiş gözüyle bakarlar:

Gelse ger bî-direm-i eşk diyâr-1 aşka

Bunca emvâl ile müflis diyeler Kâruna （Hayâlî, G. 491-4)

Zâtî beyitte sevgiliye istiare yoluyla geçici bir ad vererek hâce diye seslenir. Giydiği elbiseler, aşk derdiyle çektiği sıkıntılardan altın gibi sararan teninin kesesi gibidir. Sevgilinin böyle değerli bir âşık olduğu için kendisine yaslanmasını ister. Hâce kelimesinin asıl anlamı olan tüccarı düşündügümüzde para ile ilgili kullanılan tabirler daha iyi anlaşılacaktır:

Tenüm altun libâsum kîsesidür gel beni yasdan

Disünler kim o hâce kîse-i dînâra yasdanmış

(Zâtî, G. 595-4)

Dirhemin para birimi olması haricinde ağırlık ölçüsü olarak kullanımı da söz konusudur. Ayşe Teymûrî sevgiliye güvenmediğini ifade ederken kelimenin bu anlamından yararlanır:

Sende bulaydım ey güzel hakikatin bir dirhemin

Ayagina serper idim sadakati kantâr ile

(Ayşe Teymûrî, Müfret 11)

Dünya malının, zenginlik göstergesi olan paranın insan için aslında büyük bir felaket olduğunu Usûlî bu beytinde dinarı ateşe belki de cehenneme benzeterek ifade eder:

Ki letdir devleti dînârıdır nâr

Olupdur nûşu nîş ü mâlı hem mâr (Usûlî, M. 4-11)

\section{Eşrefî̀}

Mısır Memlüklüler hâkimiyetindeyken burada basılan altın paranın ismidir. Yavuz Sultan Selim Mısır'ı aldıktan sonra burada adına bastırdığg altın paralara da Mısırlılar tarafından bu isim verilmiștir (Pakalın, 1983: 564). 
Necâtî Beyin Sultan Bayezit için yazdığı kasidenin bir beytinde güneş eşrefi altını gibi düşünülmüştür. İnsanlar rızıklarını aramak ve geçimlerini sağlamak için çalışmaya sabah güneş doğduktan sonra başlar. Onun adaletle hüküm sürdüğ̈ saltanat zamanında seher, insanların geçimini sağlaması için her sabah vakti bir eşrefi ihsanda bulunur. Beyitte hüsn-i talil sanatı yapılarak eşrefi altınına benzetilen güneş, doğuşunu padişahın adaletli eliyle insanların geçimini sağlamasına borçlu olarak düşünülmüştür:

Adlin eliyle âleme kesb-i ma'âş için

Her subh-dem bir eşrefi eder atâ seher

(Necâtî Bey, K. 9-38)

\section{Filori}

İtalyanca filorinden gelen bu kelime 12. yüzyılda Floransa'da basılan paranın adıdır. 1252 yılına kadar gümüş olarak basılmış, bu tarihten sonra ise altın şeklini almıştır. Bir yüzünde Floransa'nın sembolü olan zambak motifi, diğer tarafında ise Vaftizci Yahya'nın resmi bulunan 3,5 gram ağırlığındaki bu altın para İtalyan devletlerinin Türkmen beylikleriyle olan ticaret bağlantıları sayesinde Batı Anadolu'da oldukça yaygın şekilde kullanılmıştır. Fâtih Sultan Mehmet dönemine kadar filori adıyla Osmanlılarda en çok kullanılan altın para durumunda olan filori, daha sonra Osmanlılar tarafından altın para karşılığı olarak hem kendi bastıkları hem de Avrupa menşeli olanlar için kullanılmaya başlandı. Fâtih'in bastırmış olduğu ilk altın sikke Venedik dukası veya filori ile aynı ayardadır (İnalcık, 1996: 106).

Keçecizâde İzzet Molla'ya ait bu beyitte güneşin ışıklarını saçması filori saçılması şeklinde düşünülmüştür. Beyitte saçı geleneğine de telmihte bulunulur:

Olup zîb-i gerdûne-i zer-nigâr

Güneş gibi etdim filori nisâr （Keçecizâde İzzet Molla, M. 628)

Vücûdî ise beyitte filoriyi kişileştirmiş ve ağırlık ölçüsü olan dirhemi kullanmıştır. Filori insanlar içerisinde ne kadar değerli olduğunu anladığı için kendisini ona direm direm satmaktadır. Direm kelimesinden nazlanarak veya ağır ağır anlamı çıkarılırsa şairin maddi anlamda bu parayı kolay ele geçiremediği, istediği kazanca sahip olamadığı da anlaşılabilir:

Gördi filori hüsnüñüñ ] elde revâcını

Kendüyi ol baña satar oldı direm direm ～(Vücûdî, M. 3468)

Emrî ise baharı bir satıcı, bağı ona müşteri, yeşillik elbisesini satılan meta olarak düşündügü beytinde alışverişte kullanılan para filoridir:

H1l'at-i sebzini geydürmiş idi bâga bahâr

Etegi tolu filoriye satupdur erzân (Emrî, K. 1-15)

\section{Füls-i Ahmer}

Füls şeklinde de kullanılır ve bakırdan yapılan paraya denir. Ahmer ise bakırın kırmızı olmasından dolayı halk tarafından verilmiş bir isimdir (Pakalın, 1983: 637). Altın ve gümüş paralarla kıyaslandığında daha değersiz olması şiirlerdeki kullanımlarında kendini hissettirir.

Divan şirinde gözden akan yaşın para ile ilişkilendirildiği durumlarda onun genellikle gümüşe benzetilmesi söz konusu olur. Şeyhülislâm Yahya gözünden akan kanlı gözyaşlarını nakde benzettiği beytinde sevgilinin bu yaşlara füls-i ahmer kadar değer vermediğinden şikâyet eder:

Bulmadı bir füls-i ahmerce yanunda i'tibâr

Nakd-i hûn-1 eşk-i çeşmüm yok yire itdüm telef （Şeyhülislâm Yahya, G.172-3) 
Bazen yukarıdaki beyitle tam tersi bir anlam ilişkisiyle, şairler tarafından değerli olması bakımından ele alınmaktadır. Renk ilgisi bakımından kırmızı renkli bakır para fülsü, gözden akan kanlı yaşa benzeten Hasan Ziyầî padişah olarak adlandırdığı sevgilinin huzurunda kendisinin tüm bu zenginliğine rağmen köle konumuna düştüğünü söyler:

Füls-i eşk-i çeşm hadsiz var iken

Pâdişâhum her gedâ müflis midür (Hasan Ziyầî, G. 113-4)

Lâmiî Celebi'ye ait bu beyitte ise güneş kızıllığı bakımından füls-i ahmere benzetilmiştir:

Mi'yâr-1 himmetünde hurşîd füls-i ahmer

Mîzân-1 hașmetünde eflâk vezn-i dirhem

(Lâmiî Çelebi, M. 1045)

Hayâlî, yaratılışını ve şairlik yeteneğini övdügü beyitte kendindeki bu özellikleri maddi unsurlarla kıyaslar. Dünya nimeti olan mal, mülk ve zenginlik bu özellikleri yanında fülûs-1 ahmer kadar bile değerli değildir:

Cevâhir-i suhanım var tabî́atimdir kân

Fülûs-1 ahmere degmez yanımda mâl-i menâl (Hayâlî, K. 10-18)

\section{Kizll}

Kızıl altın, kızıl bakır, kızıl akçe, kızıl mangır gibi altın, gümüş veya bakırdan darp edilen para birimleriyle birlikte kullanılan kızıl kelimesi özel bir para biriminin adı değildir. Ancak tıpkı çil kelimesinde olduğu gibi darphanede basılıp tedavüle yeni çıkan paralar için kullanılan bir tabirdir.

Kızıl kelimesi para birimleri için yeniliğin, kalitenin ve değerli olmanın bir ifadesi olarak görülür. Revânî ve Behiştî̀ye ait beyitlerde âşığın sahip olduğu en değerli şeyler bu paralara teşbih edilir. Bu bazen âşığın sinesi bazen de sararmış yüzüdür. Bazen de sevgilinin ayağı altında yüzünü toprak eden âşığın kısmetli hali, yolunda giden işi kızıl altın olarak görülür.

Sîmîn bedenlerle sînem kızıl altundur

Sarrâfi durur çeşmüm gönlüm mihek olmışdur

(Revânî, G. 49-4)

Çihre-i zerd-i Behiştîye nazar kılmazsın

Kıymeti yok gibi yanuñda kızıl altunuñ

(Behiştî, G. 275-5)

Hâk eylemişem yüzümi zîr-i kademünde

İşüm kızıl altun senün ey şeh kademünde (Revânî G. 400-1)

Behiştî, sevgilinin uğruna feda edeceği hiçbir şeyin ona layık olmayacağını söylerken onun yoluna akıtacağı kanlı yaşların kızıl mangır dahi olmayacağını söyler:

Kanlu yaşum kim zer-i surh ile hâşâ bir degül

Yolına döksem yanında bir kızıl mangır degül

(Behiştî, G. 306-1)

Kanlı yaşın kızıl akçeye benzetildiği bu beyitte ise Emrî, sahte para basan kallâb ile rakibi ilişkilendirmiş ve onun sevgiliyi kandırmak için yaptığı sahtekârlığı haykırmıştır:

Kallâbdur rakîb kızıl akça harcanur

Dilber görüp gözinden akan kanlu yaş sanur ～(Emrî, Kıt’a 72-1)

\section{Mangir}


Moğolca altın, gümüş para anlamına gelen mungun veya mongon kelimesinin Türkçeye geçmiş hali olan mangır bakır paraya verilen isimdir. Halkın bozuk para ihtiyacını karşılayan mangır, akçenin küsürlerindendir (Pakalın, 1993a: 405). Divan şiirinde de genel olarak azlığı, değersizliği ifade ederken kullanılır.

Behiştî olumlu gözle bakılmayan vaize seslenirken, onun verdiği nasihatlerin geçersizliğini ifade ederken ayrıca akıttığı gözyaşlarının sevgilinin nazarında değersizliğini anlatırken mangırı kullanır:

Yüri vaktüñde ol vấiz yeñi bir mankıra geçmez

Diyâr-1 'ş̧̧ sarrâfı yanında cevher-i pendüñ

(Behiştî, G. 269-4)

Mangıra geçmedi yaşum sîmi

Mâlik oldı metâ'-1 vuslata gayr

(Behiştî, G. 154-2)

Mangır şairler tarafından söyledikleri şiirlerin değerini veya değersizliğini ifade etmek için de kullanılmıştır. Tırsî, beyitlerinin insanlar tarafından dikkate alınmamasını mangırın değeri düşük ve sahte züyûf akçe ile kıyaslamasını yaparak dile getirirken Behiştî ise tam tersi bir durumdan bahseder. Mana âleminin cevheri olan beyitleri onlardan anlamayanlar tarafından mangır gibi değersiz görünse de bu durumun bir önemi olmadığını dile getirir:

Mankır-âsâ kâle gelmez mashara ebyâtumuz

Bir züyûf akçe gibi hemyâna girmiş çıkmışuz

(Tirsî, G. 80-6)

Her beyti anuñ 'âlem-i ma'nâ güheridür

Bir mangıra almazsa ne noksân anı nâdân

(Behiştî, K. 3-79)

Nakit

Nakit genel anlamda para demektir. Nasıl ki alışveriş için gerçek anlamda para vazgeçilmezse sevgiliyle bir nevi alışveriş halinde olan âşık için en değerli şeyleri bu ilişkide bir nakittir.

Bu nakit İshak Çelebi için ölmeden kapatılması gereken bir borç gibi görülen gönül ve candır:

Gel begüm gel dil ü cân nakdini teslîm idelüm

Ölmedin borcumuzı sana edâ eyleyelüm

(İshak Çelebi, G. 182-3)

Sünbül-Zâde Vehbî ise aşk pazarında sevgiliyle girdiği ticarette kavuşma metaını rakibe verdiği için uğradığı zarar yüzünden akıl nakdini kaybetmekten şikayetçidir:

Metâ'-1 vaslı verdi gayra nakd-i 'aklım almışken

Ziyâna ugradım bir şâhid-i bâzâra çarpıldım

(Sünbül-Zâde Vehbî, G. 185-4)

Şeyhülislâm Yahya sevgilinin yanında bir değeri olmayan kanlı göz yaşını nakit olarak düşünürken Nâbî ise elinde gözyaşı nakdinden başka bir sermayesinin olmadığının farkındadır:

Bulmadı bir füls-i ahmerce yanunda i tibâr

Nakd-i hûn-1 eşk-i çeşmüm yok yire itdüm telef （Şeyhülislâm Yahya, G.172-3)

Hemân bir nakd-i eşküm var dahi yok

Budur sermâyem elde az eger çok (Nâbî, Şehrengiz 8)

Nevizâde Atâyî şiirini, sevgiliye kavuşma metaına sahip olmak için ona beşer beşer saydığı bir nakte benzetir:

Metâ'-1 vasl-1 yâre tâlib olup nakd-i nazm ile

'Atâyî saydum ol Yûsuf-cemâle ben anı beş beş

(Nevizâde Atâyî, G. 110-5) 
Nedîm bu ticaretten umutludur. Eğer onu ikna edebilirse sevgilinin can bahşeden bûsesine hayat nakdini vermeye hazırdır:

\author{
Bir bûse-i can-bahşına ver nakd-i hayâtı \\ Ger kâ'il olursa \\ Senden yanadır söz yine bâzâr senindir \\ Ey âşık-1 şeydâ
}

(Nedîm, Müseddes 2-4)

Nâilî ise dini bir nakit olarak düşünmüştür. Alın yazısı, sevgiliye kavuşma kumaşını elde edebilmek için din nakdinin verilmesine hükmetmiştir. Bu hükmün karşısında çaresizdir ve hükmün gereğini yerine getirecektir:

Etmiş ne çâre hükm-i sevâd-1 cebînimiz

Kâlâ-yı aşk-1 yâre fedâ nakd-1 dînimiz

(Nâilî, G.152-1)

Nâbî beyitte ekonomik hayatın toplumsal bir boyutunu anlatır. Bazı durumlarda, özellikle piyasalarda durgunluğun olduğu zamanlarda para piyasada pek görülmez. İnsanlar harcamama eğilimi gösterir ve piyasalarda daralma olabilir. Bu durumda vatandaş yatırım yapma düşüncesiyle hareket eder. Nâbî böyle zamanlarda keselere saklanan parayı veya saf kelimesinden hareketle altın parayı şairlerin gönüllerinde saklı kalıp dile getirilmeyen orijinal fikirlere benzetir:

Sîneden elsineye saçar emîn macnî-i sâf

Benzer ol nakde ki bî-sûd yatur mahzende

(Nâbî, G.805-6)

Nevizâde Atâyîye göre hüner değerli bir nakittir. Ulemadan Kemâl Efendi için yazdığg kasidede onun zamanında hünerin ticaret için gerekli olan nakit bir sermayeye benzediğini söyler:

Revâ mı fầidesin görmeyem zamânında

Elümde nakd-i hüner gibi ola ser-mâye

(Nevizâde Atâyî, K.12-39)

\title{
Nuhas
}

Kelime bakır veya bakır para anlamına gelir. Bakır paralar en değersiz para birimleri oldukları için divan şiirinde nuhas, genellikle kötülükle dolu veya kötü düşünceler barındıran kalple ilişkilendirilir.

Beyitte gümüş, bakır gibi değeri altına göre daha düşük olan madenlerin iksir adıverilen maddeyle altına dönüştürülmesi yollarını arayan simya ilminden bahsedilir. Hamdullah Hamdî, istiare yoluyla kalbi nuhâs olarak nitelendirir. Nuhâs olan kalp ancak aşk iksiriyle altın para olan şâhî sikke gibi değerli bir altın paraya dönebilir. Ahmed-i Rıdvân da kalbin böylece arınabileceğini ve pasının gideceğini ifade eder:

Zer it nuhâsunı iksîr-i 'sşk ile Hamdî

Ki lâyık ola ana vaz'-1 sikke-i şâhî̀ (Hamdullah Hamdî, G. 152-5)

Ola kalbüm mücellâ gide pâsum

Zer-i hâlis kıla işbu nuhâsum （Ahmed-i Ridvân, M.1480)

Bazen de bu iksir "lâ ilâhe illallah" lafzıdır:

Zer ider kalbini nuhâs olanuñ

Cevher-i lâ ilâhe illallâh

(Ravzî, K. 2-59)

Metîn ü sağ olurmış Anatolı çocuğı 
Girân-bahâdur anun-çün beli nuhâs-i dü-kat （Tirsî, G. 29-2)

\section{Nukre}

Nukre, külçe şeklinde bulunan gümüştür. Nâbî gözyaşının çokluğunu gümüş külçesine benzettiği beytinde, Kârûn'un tüm hazineleri ile Allah tarafından toprağa gömülmesine telmihte bulunmuş ve bu olayın sebebini hüsn-i talil yoluyla manevi zenginlik olarak nitelediği gümüş külçesi gibi çok olan gözyaşlarına bağlamıştır:

Kesret-i nukre-i eşküm haberin almış kim

Zîr-i hâk itdi hased mâlı ile Kârûn'ı (Nâbî, G. 873-3)

Âgâh, beytinde talip olunan bir şeyin kolay elde edilemeyeceği gerçeğini Hz. Yusuf kıssasına telmihte bulunarak ifade eder. Gözden akan yaş nukre olarak düşünülmüştür. Babası Yakup peygamber dahi olsa Yusuf un güzellik kumaşına sahip olmak kolay değildir. Onun gömleğinin kokusu çok kolay ele geçmez. Bunun için gözden nukre gibi, külçe kadar yaş akıtmak gerekir:

Kumâş-1 hüsn-i Yûsuf nukre-i çeşm-i sefîd ister

Muhassal râygân Yakkûba bûy-1 pîrehen düşmez ～(Âgâh, G. 167-3)

Nevizâde Atâyî, ilkbahar rüzgârını kişileştirdiği beytinde bu rüzgârı çemen şehrine çiçek yapraklarını gümüss paralar gibi süren ve piyasayı canlandıran bir satıcı olarak düşünür:

Meger bâd-ı bahârî oldı kırtâsiyeye mâlik

Sürer şehr-i çemende nukre-veş evrâk-1 ezhârı ～(Nevizâde Atâyî, K.8-17)

Fuzûlî kişiliğin düzgünlüğünü, Nâbî ise içinde bulunduğu maddi sıkıntıyı ifade ederken başparmağındaki tırnağı nukreye benzetmiştir:

Şikest nukre-i hâlis-' iyârıma koydu

İyâr-1 nukre-i zâtında ihtimâl-i küsûr （Fuzûlî, K. 2-14)

Ser-engüştümdeki nâhundan özge nukre girmez hîç

Benüm cîb-i ümîdüm kîse-i dellâke dönmişdür

(Nâbî̀, G. 66-5)

\section{Para}

Kuruşun kırkta birine denk gelen ve 17. yüzyıldan itibaren kullanılan bir paradır (Pakalın, 1993a, 752). Lebîb, saba rüzgârının çiçek yapraklarını tıpkı çil paralar gibi gül bahçesine saçtığını söyler. Bahar gelmiştir. Ortalık yeniçerilere üç ayda bir verilen asker aylıklarının dağıtıldığı gibi olmuş, bereketlenmiştir. Devletin maaşları verdiği gün piyasalar, çarşı-pazar nasıl hareketlenir ve piyasalarda para döner, herkesin yüzü gülerse gülşene saba çil paralar gibi yaprakları dağıtınca her tarafı mutluluk kaplamıştır:

Sabâ çil para saçdı gülşene ezhâr-1 bâdâmı

Hevâ gûyâ mevâcib-dâde-i Bektâşiyân oldu ～(Lebîb, K.6-8)

Sîne-i sad-pâreye çalmak revâ mı tîgını

Anı artuk paraya ol âfet-i cân çalmasun （Mânî, G. 74-3)

Pul

Kuruşun küsuratlarından en az değere sahip olan bir para birimidir. Kuruşun diğer küsuratları ise para ve akçedir. Bir kuruş kırk para, bir para üç akça, bir akça üç pula denk gelmektedir (Pakalın, 1993a, 781). Şiirlerde maddi olarak yetersizliği ifade eden "bir pula muhtaç olmak" deyimi içinde kullanımı sıklıkla görülen pul, bu anlamın ötesinde para haricinde kaybedilen şeyleri ifade etmek 
içinde kullanılmaktadır. Gelibolulu Mustafa Âlî̀ye ait bu beyitte çiçekleri yağmalanan bir gül bahçesi ve bu bahçede çiçekleri kaybettiği için yokluğa düşen güller şahından bahsedilir:

\section{Hayli ezhârı kıldılar târâc}

\section{Şâh-1 gül kaldı bir pûla muhtâc ～(Gelibolulu Mustafa Âlî, M. 1051)}

Bazen de bu kaybedilen şey, kişinin değerini insanlar nazarında yücelten adıdır. Ad, insanın yaptığı güzel şeyler karşısında elde ettiği nam ve ündür. Kötü işler yapan kişinin toplum nazarındaki karşılığı pul gibi değersiz olmaktır:

\section{Ad-1la işler-imiş kişi işi}

Bir pula degmez-imiş adsuz kişi （Gülşehî , M. 1260)

Yine insanın değer ve kıymeti divan şiirinde para birimleriyle ilişkilendirilmektedir. Niyâzî Mısrî, değeri veya itibarını kaybeden kişiyi pul kelimesi ile anlatmıştır:

Kiminin bakırını eder altın

Kiminin altının kara pul eyler (Niyâzî Mısrî, G. 131-3)

Âşık Paşa insan bedenini, ona değerini veren gönül ve canı para birimleriyle ifade eder. Gönlü de pula benzetir:

Pul dilüñdür hem gümiş tendür 'ayân

Ol kızıl altun bilüñ cândur beyân (Âşık Paşa, M. 1433)

\section{Peşiz}

Pul, akçe, mangır (Devellioğlu, 2012: 1010) anlamlarına gelen bir kelimedir. İncelenen eserlerde Nâbî divanındaki bir beyitte karşımıza çıkmıştır. Beyitte tabiat unsurları ve gökyüzüne ait kelimelerle alış-veriş manzarası canlandırılmaktadır. Burada dellal felek, satılan ise yıldız cevherleridir. Satışın yapıldığı yer sabah vakti kurulan çarşıdır, kullanılan para ise peşizdir:

Gevherân-1 ahteri dellâl-i çerh eyler fürûht

Çâr-sûy-1 subhgehde bir peșiz eylerse de （Nâbî, G.723-4)

\section{Sikke}

Madeni paraların üzerine, kıymetinin devlet tarafından güvence altına alınıp bu paraların resmî hüviyet kazanması amacıyla vurulan nakış, damga veya mühürdür. Ayrıca genel olarak para anlamına da gelmektedir (Tekin, 2009: 179. Pakalın, 1993b: 214).

Süheylîye göre asıl önemli olan bu sikkeyi iyi bir ad bırakmak için vurabilmektir. Cömertliğiyle ünlü Hâtem her ne kadar görünüşte sahip olduğu maddi varlığı, üzeri damgalı, mühürlü paraları insanların hizmetine vermiş gibi görülse de onun asıl özelliği yapmış olduğu cömertliğin bu dünyada sikke gibi değerli olmasıdır. Zaten insan öldükten sonra ondan geriye kalan yaptığı cömertlik ve bıraktığı güzel addır:

Sehâ mührin urup bir sikke komış âleme Hâtem

Soñında herkesüñ bâkî kalan bir ad imiş bildüm

(Süheylî, G. 214-6)

Hayâlî Bey ise karşımıza sikke ve hutbe kelimelerinden hareketle bir sultan imajı çıkartmaktadır. İslam devletlerinde sultan tahta geçince hükümdarlığının geçerli olması ve gücünün halk tarafından kabul görmesi için adına hutbe okutup para bastırmaktadır. Beyitte âşık dert sultanıdır. Bu ülkenin sultanı da gözyaşı gümüşünden bastırdığı sikkeler ve okuttuğu aşk hutbesiyle hiçbir ortağı olmadan, tek başına odur: 
Sîm-i eşkinden yürütsün sikkesin ol şâh-1 derd

Hutbe-i aşk adına bî-iştirâk olmak gerek (Hayâlî Bey, G. 301-4)

Âşık Çelebi de âşık için sultan mazmununu kullanır. Burada hutbe âşı̆̆ın aşk derdiyle inlemesi,

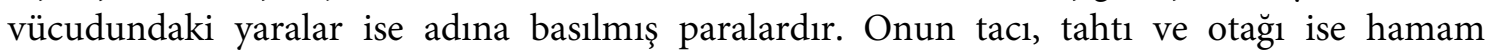
külhanıdır:

Okınur hutbe-i nâlem kazılur sikke-i dâgum

Otag u tâc u tahtum yog ise külhen bucagum var (Âşık Çelebi, G. 83-4)

Divan şairleri sözlerinin kıymetli olduğunu, insanlar ve özellikle gönül verdikleri güzeller tarafından kabul görmesini sıklıkla dile getirmişlerdir. Bunu yaparken kullandıkları benzetme unsurlarından biri de kıymet ifade etmesi açısından para ve bununla ilgili unsurlar olmuştur. Keçecizâde İzzet Mola şiirinin her yerde insanlar tarafından kabul gördüğü düşüncesini, üzerine sikke vurulup geçerliliği ve değeri artan altın para ile ilişkilendirir:

\section{Zer-i nazmımı eyledi sikkevâr}

Sözüm her mahalde geçerse ne var (Keçecizâde İzzet Mola, M. 1259)

Nefî de en değerli paranın yeni basılmış altın para olduğu gerçeğinden hareketle kendi sözlerinin değerini, insanlar içinde ona verilen değeri bu altın paraya benzetir. Bir anlamda sözün sultanı olduğunu, tertemiz ismiyle nazmın alnına sikkeyi vurarak göstermiştir:

Zer-i nev-sikke kadar rağbeti var sözlerimin

Nâm-1 pâkin edeli nâsıye-i nazma rakam

(Nefî, K.51-44)

Âgâh ise mübalağa sanatını kullanarak söz nakdinin sürümünün veya değerinin olmadığı bir zamanda atasözü sikkesi gibi sözlerinin değil insanlar, güzeller arasında bile revaç bulduğu iddiasında bulunur:

Nâ-râic iken nakd-ı suhan pek geçer oldı

Hûbâna bile sikke-i darbü'l-meselümden

(Âgâh, G. 291-6)

Ravzî de rakibin sahtekârlığını sikke-sûret ibaresiyle ifşa eder. Ey sevgili! Rakip her ne kadar kendini para gibi değerli göstermeye çalışsa da sarraf ona asla bir değer vermez. Onun sahte para gibi değersiz oluşu işin ehli tarafından rahatlıkla anlaşılır:

Gerçi kim bir sikke-sûret kimsedür cânâ rakîb

İtmedi ta'yîn-i kıymet lîk bir sarrâf aña

(Ravzî̀, G. 5-2)

\section{Sultânî}

Yavuz Sultan Selim'in Misır'ı fethinden sonra Misır'da özellikle de Trablus, Tunus ve Cezayir darphanelerinde basılan 0smanlı altınları hakkında o bölge insanı tarafından kullanılan bir isimdir (Pakalın, 1993b: 276). Bursalı Rahmî sevgiliye duyulan aşkı sultânî altınlarıyla dolu bir hazineye, bu aşkın barındığı sinesini ise hazinenin saklı olduğu mahzene benzetmiştir:

'Işkun ki ezel sînemüzi eyledi mesken

Gencîne-i sultânî idi mahzene geldi （Bursalı Rahmî, G. 221-6)

\section{Sülüs}

Sikkenin üçte bir ağırlığındaki bir madeni paranın adıdır (Devellioğlu, 2012: 1132). Nâbî̀ye ait bu bentte devirden, zamandan veya dünyadan şikâyet edilir. Şair para birimlerinden, bunların ayarlarının bozukluğundan ve sahteliğinden hareketle dünyanın düzeninin bozulmuşluğunu ifade eder. Bentte aynı zamanda bir kuruşun üç sülüse denk geldiği gerçeği de ifade edilir: 
Üç sülse bir kara guruşı bozdı rûzgâr

Birisi kalb biri kızıl birisi züyûf

Sarrâf- 1 dehr didi görince bu hâleti

Üç süls-i kem-'iyârına la'net gurûşa yûf

(Nâbî̀, Kıt’a 49)

\section{Şâhî}

İran kökenli olan bu isim Timur'un oğlu Şâhruh'un adına nisbetle önce şâhruhî şeklinde kullanılan daha sonra kısaca şâhî olarak yaygınlaşan bir çeşit gümüş paranın adıdır. Osmanlı devleti, Akkoyunlu ve Safevî dönemlerinde İran'da basılan şâhruhî (şâhî) gümüş sikkesini Osmanlı parası olarak Yavuz Sultan Selim'in İran seferi ve buralardaki fetihlerinden sonra bastırıp kullanmaya başlamıştır. Osmanlı topraklarınsa altın sikkeye de zaman zaman bu isim verilmiştir (Maxım, 2007: 143-144). Hamdullah Hamdî̀ye ait beyitte kimya ilminden hareketle bakırın iksirle altına çevrilmesi hadisesine telmihte bulunulmuştur. Burada bakır kalptir ve o, aşk denilen iksirle altına dönüşür. Böylece ona sikke-i şâhî adı verilmesi uygun olur. Nasıl ki altına kıymetini verip ona şâhî adını verdiren üzerindeki sikkeyse kalbi kötülüklerden arındıran da aşktır:

Zer it nuhâsunı iksîr-i 'ișk ile Hamdî

Ki lâyık ola ana vaz'-1 sikke-i şâhî̀ （Hamdullah Hamdî, G. 152-5)

Hayâlî Bey ise aşağıdaki beyitte sultan olarak sevgiliye seslenirken "sikke-i şâhî"den söz eder. Nasıl ki altın, üzerine şâhi sikkesi vurulduğunda değer kazanırsa âşığın sararmış yüzünün kıymeti de sevgilinin köpeğinin buraya ayak basmasıyla artar. Bunun gerçekleşmesi için, değil sevgilinin ayağı, onun köpeğinin ayağı bile yeterlidir:

Kadrim artar ruh-1 zerd üzre itin bassa kadem

Sikke-i şâhi ile mu’teber olur altun （Hayâlî Bey, G. 410-2)

\section{Zincirli}

Sultan III. Ahmet (1703-1730) zamanında basılmış, ayarı yüksek altın sikkelerden birinin adıdır. Etrafındaki tırtıllara zincir dendiği için bu adı almıştır (Kolerkılıç, 1958: 92. Pakalın, 1993b: 663). Arpaemînizâde Sâmî sonbaharı, zincir altından oluşan paralarını hesaplayan bir hazinedara benzetmiştir:

Eyler hisâb nakd-i zerin hâzin-i hazân

Zencîr-i hurde-mevce-i cûdan döküp rakam （Arpaemînizâde Sâmî, K. 10-4)

\section{Zer-i Mahbūb}

III. Ahmet zamanında basılan altın sikkelere genel olarak fındık altını denmiştir. Bunlardan ayar, vezin ve değer yönünden farklı olanlardan birinin adı da zer-i mahbūbdur. 1729 yılında basılmıştır (Kolerkılıç, 1958: 92. Pakalın, 1993b: 655). Bu para birimi söz konusu olunca âşık ile sevgili arasındaki ilişki ön plana çıkmaktadır. Vücûdî, âşığın sevgiliye olan aşkından ötürü sararıp solan yüzünü bu altın paraya benzetir:

Çehre-i 'âşıkı sanup zer-i hûb

Sille vü müşt ile döger zerkûb
(Vücûdî, M. 1516)

\section{Sonuç}

Para, ortaya çıktığı dönemden bu yana toplumlarda sadece maddi hayata değil insanlar arasındaki ilişkilere de etki eden unsurlardan biri olmuş; kişinin toplumdaki yeri ve ona verilen değer, sahip 
olduğu paranın miktarı ve değeriyle ilişkilendirilmiştir. Bunun yanında paranın görünen maddi değeri haricinde insanın manevi yönünü ifade eden tarafları da mevcuttur. Bu çalışmada akçe, altın-gümüss, bakır, çil, dinar ve dirhem, eşrefi, filori, Firengî, füls-i ahmer, kızıl altın, mangır, nakit, nuhas, nukre, para, peşîz, pul, sikke, sultânî, sülüs, şâhî, zer-i mahbūb ve zincirli başlıklarından hareketle bahsi geçen bu para birimleri veya paranın basıldığı madenlerin manevi değeri üzerinde durulmuştur. Farklı yüzyıllarda eser veren divan şairlerinin divan ve mesnevilerinden hareketle yüzyıllardır Türk insanı tarafından kullanılan atasözlerinde, çeşitli deyimlerde, âdet ve geleneklerde paranın nasıl işlendiği; Âşı̆̆ın gözünden dökülen yaşın, sararmış yüzünün, vücudundaki yaraların altın, gümüş ve bakır paralara nasıl benzetildiği; paranın değeri, ayarının bozukluğu veya sahte olmasıyla insan kişiliğinin nasıl ilişkilendirildiği; felek, baht, talih, doğa ve tabiat olayları, insan teni, kalp, can, akıl, şairlerin şiir söyleme yetenekleri ve şairlik güçleri gibi unsurlarla nasıl ele alındığı anlatılmaya çalışılmıştır.

\section{Kaynakça}

Akdağ, Mustafa (2014). Türkiye’nin İktisadi ve İçtimai Tarihi. İstanbul: YKY.

Akkuş, Metin (hzl.) (1993). Nefî Dîvânı. Ankara: Akçağ Yayınları.

Akpınar, Şerife (hzl.) (2012). Âgâh Dîvânı. http://ekitap.kulturturizm.gov.tr (erişim tarihi: 02.07.2014).

Akyıldız, Ali (2007). “Para”. Türkiye Diyanet Vakfı İslâm Ansiklopedisi. Cilt no:34. İstanbul: Türkiye Diyanet Vakfı Yay. 163-166.

Akyüz, Kenan. S. Beken, S. Yüksel, M. Cunbur (hzl.) (1990). Fuzûlî Dîvânı. Ankara: Akçă̆ Yayınları.

Avşar, Ziya (hzl.) (ty). Revânî Dîvânı. http://ekitap.kulturturizm.gov.tr (erişim tarihi: 02.07.2014).

Aydemir, Yaşar (hzl.) (ty.). Behiştî Dîvânı. http://ekitap.kulturturizm.gov.tr (erişim tarihi: 02.07.2014).

Aydemir, Yaşar (hzl.) (2009). Ravzî Dîvânı. http://ekitap.kulturturizm.gov.tr (erişim tarihi: 02.07.2014).

Aydemir, Yaşar (hzl.) (2017). Vücûdî-Hayâl u Yâr. http://ekitap. kulturturizm.gov.tr (erişim tarihi: 07.07.2016).

Bayram, Asuman (hzl.) (2017). Firâkî-Husrev ü Şî̀în. http://ekitap.kulturturizm.gov.tr (erişim tarihi: 07.07.2016).

Bilkan, Ali Fuat (hzl.) (1997). Nâbî Dîvânı I-II. İstanbul: MEB Yayınları.

Çavuşoğlu, Mehmet, A. Tanyeri (hzl.) (1987). Zatî Divanı C. III. İstanbul: İÜ Edebiyat Fak. Yayınları.

Çavuşoğlu, Mehmet, M. Ali Tanyeri (hzl.) (1989). Üsküblü İshâk Çelebi, Dîvânı-Tenkidli Basım. İstanbul: Mimar Sinan Üniversitesi Yayınları.

Demir, Hiclal (hzl.) (2017). Lâzikîzâde Feyzullah Nâfiz ve Dîvânı. http://ekitap.kulturturizm.gov.tr (erişim tarihi: 02.07.2014).

Demirel, Şener (hzl.) (2011). Mânî Dîvânı ve Şehr-engîz-i Bursa (İnceleme-Metin). http://ekitap.kulturturizm.gov.tr (erişim tarihi: 02.07.2014). 
Devellioğlu, Ferit (2012). Osmanlıca-Türkçe Ansiklopedik Lugat. Ankara: Aydın Kitabevi.

Erdoğan, Mustafa (hzl) (2011). Bursalı Rahmî Dîvânı. http://ekitap.kulturturizm.gov.tr (erişim tarihi: 02.07.2014).

Esir, Hasan Ali (hzl.) (2017). Lâmî̀ Çelebi-Ferhâd İle Şîrîn. http://ekitap. kulturturizm.gov.tr (erişim tarihi: 07.07.2016).

Filiz, Kılıç (hzl.) (ty.). Âşık Çelebi Dîvânı. http://ekitap.kulturturizm.gov.tr (erişim tarihi: 02.07.2014).

Gürgendereli, Müberra (hzl.) (ty.) Mortarlı Hasan Ziyầ̂̀ Dîvânı. http://ekitap.kulturturizm.gov.tr (erişim tarihi: 02.07.2014).

Harmancı, M. Esat (hzl.) (ty). Süheylî Ahmed bin Hemdem Kethudâ Dîvânı. http://ekitap.kulturturizm.gov.tr (erişim tarihi: 02.07.2014).

İçli, Ahmet (hzl.) (2010). Gelibolulu Mustafa Âlî-Mihr ü Mâh. http://ekitap.kulturturizm.gov.tr (erişim tarihi: 07.07.2016).

İnalcık, Halil (1996). “Filori”. Türkiye Diyanet Vakfı İslâm Ansiklopedisi. C. 13. İstanbul: Türkiye Diyanet Vakfi Yay. 106-107.

İpekten, Haluk (hzl.) (1990). Nâilî Dîvânı. Ankara: Akçağ Yayınları.

İsen, Mustafa (hzl.) (1990). Usûlî Dîvânı. Ankara: Akçağ Yayınları.

Kalyon, Abuzer (hzl.) (2013). Ayşe Teymûrî Dîvânı. Ankara: Akçağ Yayınları.

Karaköse, Saadet (hzl.) (1994). Nev'î-Zâde Atâŷ̂ Dîvânı. http://ekitap.kulturturizm.gov.tr (erişim tarihi: 2.07.2014).

Kavruk, Hasan (hzl.) (ty). Şeyhülislam Yahyâ Dîvânı. http://ekitap.kulturturizm.gov.tr (erişim tarihi: 02.07.2014).

Kavruk, Hasan, B. Selçuk (hzl.) (2009). Vecdî ve Dîvân'ı. http://ekitap.kulturturizm.gov.tr (erişim tarihi: 02.07.2014).

Kolerkılıç, Ekrem (1958). Osmanlı İmparatorluğunda Para. Ankara: Doğuş Ltd. Şirketi Matbaası.

Kurtoğlu, Orhan (hzl.) (2004). Lebîb Dîvânı. http://ekitap.kulturturizm.gov.tr (erişim tarihi: 02.07.2014)

Kuşoğlu, Mehmet Zeki (2006). Resimli Ansiklopedik Kuyumculuk ve Maden Terimleri Sözlüğü. İstanbul: Ötüken.

Küçük, Sabahattin (hzl.) (1994). Bâkî Divanı. Ankara: TDK Yayınları.

Macit, Muhsin (hzl.) (1997). Nedîm Dîvânı. Ankara: Akçağ Yayınları.

Mihai Maxim (2007). "Şâhî”. Türkiye Diyanet Vakfı İslâm Ansiklopedisi. C. 34. İstanbul: Türkiye Diyanet Vakfi Yay. 143-144.

Orak, Kadriye Yılmaz (hzl.) (ty). İbrahim Tirsî̀ ve Dîvân'ı, İnceleme-Tenkidli Metin. http://ekitap.kulturturizm.gov.tr (erişim tarihi: 07.07.2014).

Ölçer, Cüneyt (1984). “Paralarla Tarih I.”. Tarih ve Toplum Dergisi. 3: 44-45. 
Özyıldırım, Ali Emre (hzl.) (ty). Keçecizâde İzzet Molla-Mihnetkeşan. http://ekitap.kulturturizm.gov.tr (erişim tarihi: 07.07.2016).

Özyıldırım, Ali Emre (hzl.) (ty). Hamdullah Hamdî Dîvânı. http://ekitap.kulturturizm.gov.tr (erişim tarihi: 02.07.2014).

Pakalın, Mehmet Zeki (1983). Osmanlı Tarih Deyimleri ve Terimleri Sözlüğ̈̈ I. İstanbul: Milli Eğitim Yayınevi.

Pakalın, Mehmet Zeki (1993a). Osmanlı Tarih Deyimleri ve Terimleri Sözlüğ̈̈ II. İstanbul: Milli Eğitim Yayınevi.

Pakalın, Mehmet Zeki (1993b). Osmanlı Tarih Deyimleri ve Terimleri Sözlüğü III. İstanbul: Milli Eğitim Yayınevi.

Pala, İskender (1999). Ansiklopedik Divan Şiiri Sözlüğü. İstanbul: Ötüken Yayınları.

Pamuk, Şevket (2013). Osmanlı-Türkiye İktisadi Tarihi. İstanbul: İletişim Yayınları.

Pamuk, Şevket (2014). Osmanlı Ekonomisi ve Kurumları. İstanbul: Türkiye İş Bankası Kültür Yayınları.

Sahillioğlu, Halil (1989). “Altın”. Türkiye Diyanet Vakfı İslâm Ansiklopedisi. C:2. İstanbul: Türkiye Diyanet Vakfı Yay. 532-536.

Saraç, Mehmet A. Yekta (hzl.) (ty.). Emrî Dîvânı. http://ekitap.kulturturizm.gov.tr (erişim tarihi: 02.07.2014).

Selman, Adnan Mahmud, A. Sümbül (hzl.) (2011). Mısrî Niyâzî Dîvânı. İstanbul: Şemseddin Yeşil Kitabevi.

Tabakoğlu, Ahmet (2014). Türkiye İktisat Tarihi. İstanbul: Dergah Yayınları.

Tarlan, Ali Nihad (hzl.) (1967). Zatî Divanı C. I. İstanbul: İÜ Edebiyat Fak. Yayınları.

Tarlan, Ali Nihad (hzl.) (1970). Zatî Divanı C. II. İstanbul: İÜ Edebiyat Fak. Yayınları.

Tarlan, Ali Nihat (hzl.) (1992). Hayâlî Divanı. Ankara: Akçă̆ Yayınları.

Tarlan, Ali Nihat (hzl.) (1992). Necâtî Bey Dîvânı. Ankara: Akçağ Yayınları.

Taş, Hasan (hzl.) (2010). Vusûlî Dîvânı. http://ekitap.kulturturizm.gov.tr (erişim tarihi: 02.07.2014).

Tatçı, Mustafa (hzl.) (ty). Yûnus Emre Dîvânı. http://ekitap.kulturturizm.gov.tr (erişim tarihi: 02.07.2014).

Tekin, Oğuz (2009). “Sikke”. Türkiye Diyanet Vakfı İslâm Ansiklopedisi. C:37. İstanbul: Türkiye Diyanet Vakfi Yay. 179-184.

Yavuz, Kemal (hzl.) (ty.). Gülşehri-Mantıku't-Tayr. http://ekitap.kulturturizm.gov.tr (erişim tarihi: 07.07.2016).

Yavuz, Kemal (hzl.) (2000). Âşıı Paşa’nın Garib-Nâme’si. http://ekitap.kulturturizm.gov.tr (erişim tarihi: 07.07.2016).

Yelten, Muhammet (hzl.) (ty.). Nev'izade Atayi-Sohbetü'l-Ebkar. http://ekitap. kulturturizm.gov.tr (erişim tarihi: 07.07.2016). 
Yenikale, Ahmet (hzl.) (2012). Sümbül-Zâde Vehbî Dîvânı. http://ekitap.kulturturizm.gov.tr (erişim tarihi: 02.07.2014).

Yılmaz, Nebi (hzl.) (2006). Ahmed-i Rıdvân, Rıdvâniyye. http://ekitap.kulturturizm.gov.tr (erişim tarihi: 07.07.2016). 